ARTICLE

DOI: $10.1038 / s 41467-018-03842-4 \quad$ OPEN

\title{
Disclosing the temperature of columnar jointing in lavas
}

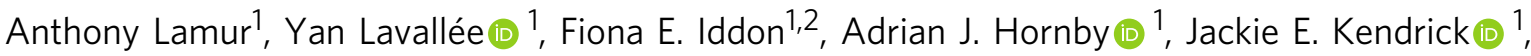
Felix W. von Aulock ${ }^{1} \&$ Fabian B. Wadsworth ${ }^{1,3}$

Columnar joints form by cracking during cooling-induced contraction of lava, allowing hydrothermal fluid circulation. A lack of direct observations of their formation has led to ambiguity about the temperature window of jointing and its impact on fluid flow. Here we develop a novel thermo-mechanical experiment to disclose the temperature of columnar jointing in lavas. Using basalts from Eyjafjallajökull volcano (Iceland) we show that contraction during cooling induces stress build-up below the solidus temperature $\left(980^{\circ} \mathrm{C}\right)$, resulting in localised macroscopic failure between 890 and $840^{\circ} \mathrm{C}$. This temperature window for incipient columnar jointing is supported by modelling informed by mechanical testing and thermal expansivity measurements. We demonstrate that columnar jointing takes place well within the solid state of volcanic rocks, and is followed by a nonlinear increase in system permeability of $<9$ orders of magnitude during cooling. Columnar jointing may promote advective cooling in magmatic-hydrothermal environments and fluid loss during geothermal drilling and thermal stimulation.

\footnotetext{
${ }^{1}$ Experimental Volcanology Laboratory, Department of Earth, Ocean and Ecological Sciences, University of Liverpool, 4 Brownlow Street, Liverpool L69 $3 G P$ UK. ${ }^{2}$ Department of Earth Sciences, University of Cambridge, Downing Street, Cambridge CB2 3EQ, UK. ${ }^{3}$ Present address: Department of Earth Sciences, Durham University, Science Labs, Elvet Hill, DH1 3LE Durham, UK. Correspondence and requests for materials should be addressed to A.L. (email: anlamur@liverpool.ac.uk)
} 
C olumnar joints form by cracking due to cooling-driven contraction of igneous rocks ${ }^{1}$, which results in tensile failure $^{2}$. Their presence in the rock record has long represented one of the most awe-inspiring geological features 3 and their regular geometry has challenged our understanding of pattern ordering during thermal contraction ${ }^{4}$. To date, the temperature of their formation has remained unconstrained, although it holds thermo-mechanical information key to resolving the cooling history of volcanic rocks ${ }^{5,6}$ and intrusive magma bodies ${ }^{7}$. Columnar joints are permeable structures that play an important role in fluid circulation in the crust, exerting controls on heat transfer ${ }^{7,8}$, resource transport and ore deposition ${ }^{9}$, geothermal and hydrothermal reservoirs ${ }^{10}$ as well as rock alteration, and degradation of rock mechanical properties ${ }^{11}$.

Columnar joints develop in cooling intrusive and extrusive volcanic rocks, irrespective of their chemical composition or emplacement environments, and have recently been discovered on Mars ${ }^{12}$. Structurally, columnar-jointed rocks classically exhibit two jointing facies: in an idealised system, a cooling unit is characterised by a lower colonnade with linear and parallel columns; and an overlying entablature with curved and irregular columns, which may be superimposed by an upper colonnade ${ }^{13,14}$. In complex bodies stress distribution can disorder column formation ${ }^{5,14}$ and occasional absence of the upper colonnade has been attributed to erosion or intense cooling regimes accentuated by abundant water incursion in a flow's interior $^{15}$. Colonnades exhibit quasi-hexagonal fracture patterns, bounded by striae (Fig. 1), the spacing of which has been shown to scale with column width, likely reflecting the cooling history of the flow ${ }^{16,17}$. The quasi-hexagonal fracture geometry has been ascribed to thermal contraction induced by conductive cooling, occasionally enhanced by water infiltration of the fracture network $^{2,16,18-20}$. The hypothesis remains that upon cooling, tensile stress accumulates elastically ${ }^{21}$, generating a random network of micro-fractures, which slowly develops into a more ordered polygonal set of mode-I tensile macro-fractures ${ }^{4}$ (Fig. 1). The

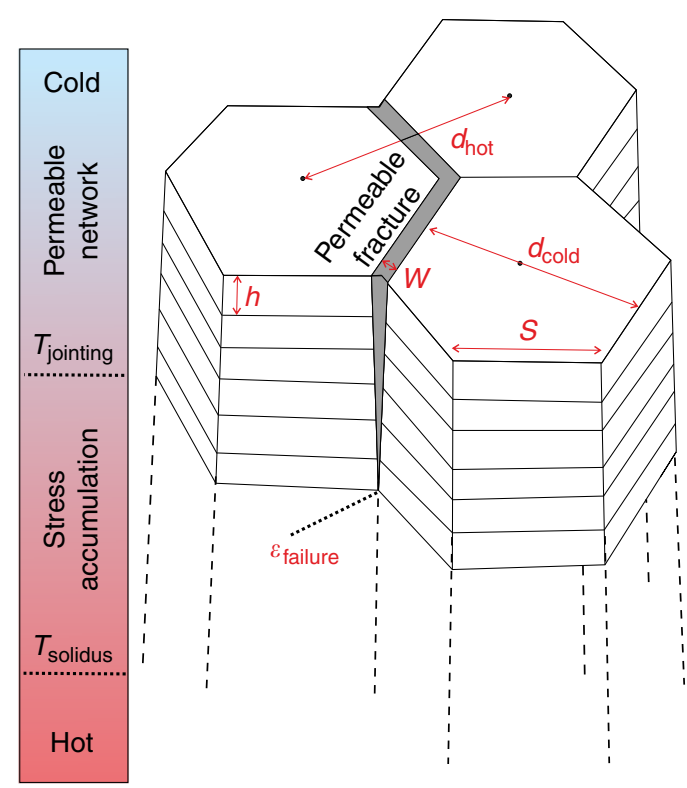

Fig. 1 Columnar jointing model. The sketch shows that tensile fractures ensue from strain accumulation, induced by thermal contraction of a length between two focal points $\left(d_{\text {hot }}\right)$, exceeding the tensile strain limit of the rock ( $\left.\varepsilon_{\text {failure }}\right)$. The length difference between $d_{\text {hot }}$ and the columnar joint diameter $\left(d_{\text {cold }}\right)$ is the width of the permeable fracture (grey area, $w$ ) along length $s$ available for fluid infiltration formation of a permeable fracture network then increases the infiltration and transport potential of fluids in the cooling body, contributing to the development of entablature ${ }^{22}$. It has previously been proposed that stress build-up and fracturing takes place during rapid cooling beyond the glass transition of the melt inside crystallising lavas (that is, at super-solidus temperatures where lava is still partially molten $)^{5,22-24}$. Semi-circular petrographic structures, present in some columnar joints, are interpreted to result from melt segregation driven by contraction and fracturing triggered during crystallisation ${ }^{1,25}$. Cross cutting of the semi-circular structure by the fracture has been used to contest fracturing of melt (undergoing the glass transition); instead melt segregation has been demonstrated to result from changes in the physical and rheological properties of melts during crystallisation ${ }^{6}$. The quenching of melt to glass relies on a relatively rapid cooling rate and predominantly high viscosities, which prevent complete crystallisation ${ }^{26}$; thus, the glass transition is more likely to be met in silicic lavas than in mafic lavas. In basaltic lava flows, vitrification is restricted to areas with very rapid cooling: the upper millimetres of a flow emplaced in $\mathrm{air}^{27}$, the fracture surface of entablatures, and in hyaloclastite and pillow lavas erupted in sub-aqueous or sub-glacial environments $22,28,29$. Here we propose that columnar joints form in the purely elastic regime of rocks; and that further cooling beyond their incipient formation results in fracture opening and therefore constructs and extends the permeable network that channels fluid flow and accentuates heat exchange.

\section{Results}

Combined thermo-mechanical jointing experiments. To test the thermo-mechanics of columnar joints we developed a novel experimental setup that allows us to directly observe fracturing in cooling lavas (Supplementary Fig. 1). In the experiment, a tensile fracture is induced by cooling a cylindrical sample of rock from its solidus temperature while locking the ends of the cylinder in position, initially imposing 0 or $5 \mathrm{MPa}$ of uniaxial compressive stress, perpendicular to the experimentally generated fracture plane (thus simulating normal stress at depth). This setup is designed to simulate elastic stress accumulation by thermal contraction between the static centres of two colonnades. Experiments were conducted on a typical, micro-crystalline basaltic lava from a jointed body at Seljavellir, at the base of Eyjafjallajökull, Iceland (Fig. 2a). The colonnades exhibit quasi-hexagonal fracture patterns, jointed into columns ranging between 30 and $130 \mathrm{~cm}$ across. The approximately regular spacing of striae, which sometimes pinch in and out laterally (Fig. 2a), scales with the column width ${ }^{16,17,24}$ (Fig. 2b). The basalt consists of plagioclase, olivine, occasional pyroxenes and iron oxide crystals (Supplementary Figs. 2 and 3), set in a micro-crystalline groundmass of the same mineralogy, which hosts no interstitial glass (Supplementary Fig. 3). The basalt has a solidus temperature of $980^{\circ} \mathrm{C}$ (at 1 bar and $\mathrm{fO}_{2}$ between nickel-nickel oxide (NNO) and quartz-fayalite-magnetite (QFM) oxygen buffers) estimated by MELTS $^{30}$ on the basis of the bulk rock chemistry (Supplementary Table 1); this was supported visually by the onset of melting of iron oxides at the starting temperature of the experiments. In the columnar jointing experiments, cooling resulted in tensile stress build-up from the solidus temperature down to temperatures of $890-840^{\circ} \mathrm{C}$, regardless of the imposed cooling rate and initial stress (Fig. 3). In this temperature range, the tensile stress accumulated $(12-18 \mathrm{MPa})$ induced failure, resulting in the creation of a throughgoing fracture and accompanying stress drop. With further cooling, the fracture widened.

Dilatometric measurements and mechanical testing. To ensure that this temperature window of columnar jointing is realistic, we 
a

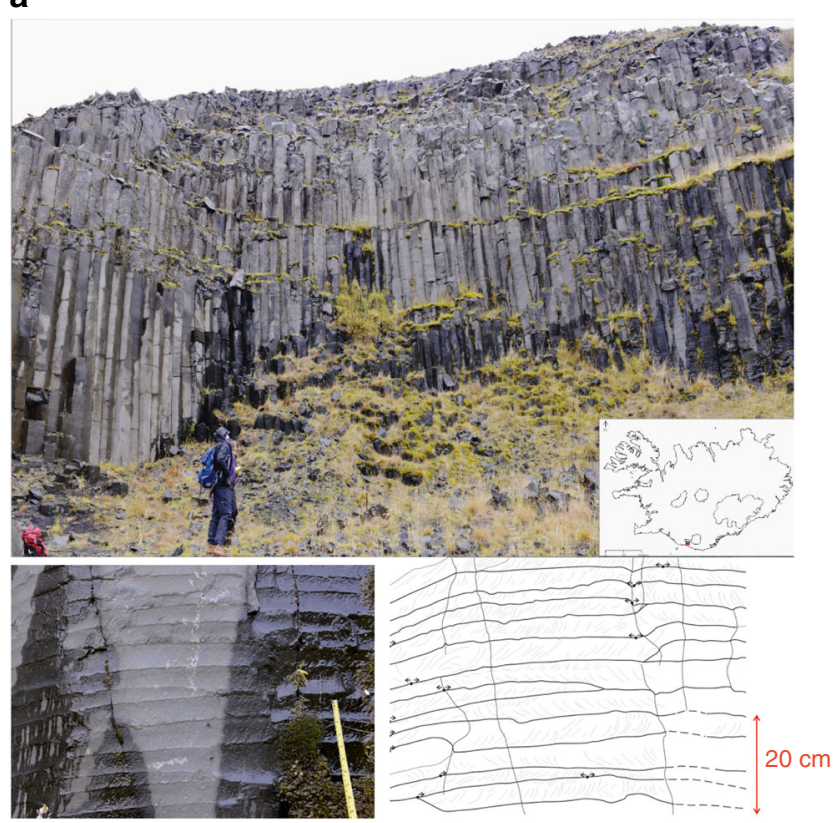

b

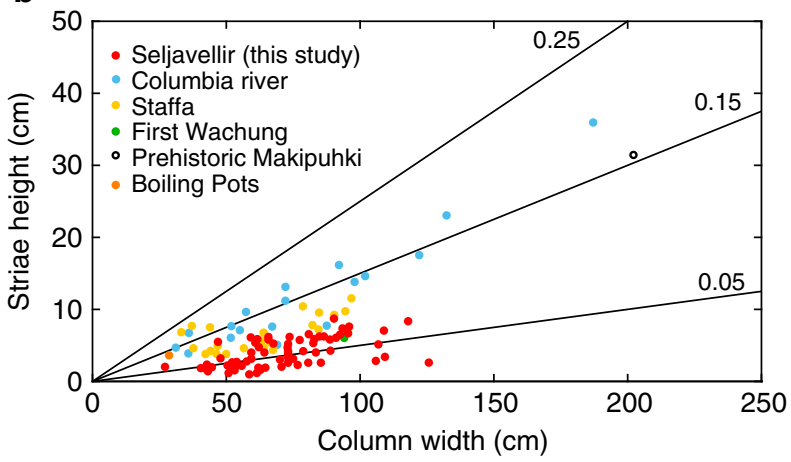

Fig. 2 Columnar-jointed basalt at Seljavellir. a Columnar joint outcrop locality complemented by a close-up photo and sketch of striae along a colonnade. The exposure is characterised by quadratic to heptagonal crosssectional patterns. The fracture surfaces reveal striae, exhibiting both a rough and a smooth portion. $\mathbf{b}$ Geometrical relationship between the height of Striae $(h)$ and the column width $\left(d_{\text {cold }}\right)$ as shown schematically in Fig. 1. The data are plotted against other columnar-jointed lavas from Columbia River ${ }^{16,17}$, Staffa ${ }^{5}$, First Wachung, Prehistoric Mahipuhki and Boiling Pots ${ }^{24}$

support our analysis with a dilatometric and mechanical study to assess whether the dynamics of columnar jointing can be explained by comparison of two distinct, static tests. Dilatometric measurements revealed that the expansion coefficient, $\alpha$, of the basalt tested is isotropic and linear in the temperature range of interest $\left(400-980^{\circ} \mathrm{C}\right.$ ), equating to $\sim 10^{-5}{ }^{\circ} \mathrm{C}^{-1}$, with rapid volumetric expansion at temperatures above $980^{\circ} \mathrm{C}$, which indicates melting and matches the solidus temperature estimated by MELTS $^{30}$ (Fig. 4). Additionally, ambient and high-temperature (820-900 ${ }^{\circ} \mathrm{C}$ ) uniaxial compressive strength tests conducted at a strain rate of $10^{-5} \mathrm{~s}^{-1}$ were used to define the temperaturedependence of the Young's modulus E (Fig. 5a). E was found to evolve according to an empirical relationship $\mathbf{E}=p \mathbf{T}+E_{0}$ (where $\mathbf{E}$ is in $\mathrm{Pa}$ and $\mathbf{T}$ is in ${ }^{\circ} \mathrm{C}$ ). Here $p=1.371 \times 10^{7}{ }^{\circ} \mathrm{C}^{-1}$ and $E_{0}=2.6157 \times 10^{10} \mathrm{~Pa}$ in the high-temperature window of columnar jointing (Fig. 5b). Finally, ambient and hightemperature $\left(600-940^{\circ} \mathrm{C}\right)$ Brazilian tensile tests constrained the tensile strength of our samples to $12-21 \mathrm{MPa}$ (Supplementary Fig. 4), in good agreement with the failure stress of $12-18 \mathrm{MPa}$ a
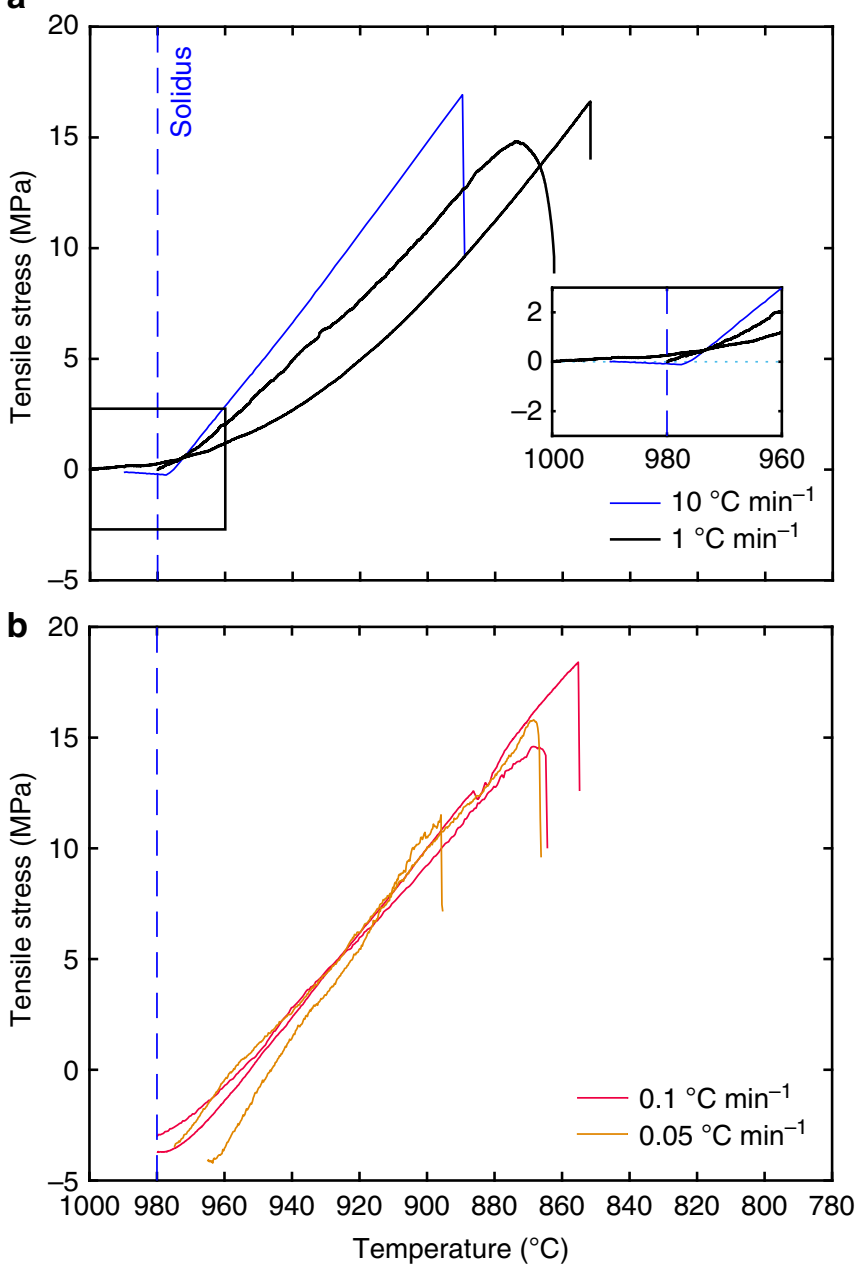

Fig. 3 Mechanics of columnar jointing. Tensile stress builds up as a rock, locked into a fixed length, cools at a set rate of 0.05 (orange), 0.1 (red), 1 (black) and $10^{\circ} \mathrm{C} \mathrm{min}^{-1}$ (blue), starting with a no applied normal stress and b $5 \mathrm{MPa}$ normal stress. The dashed blue line denotes the solidus temperature $\left(980^{\circ} \mathrm{C}\right)$

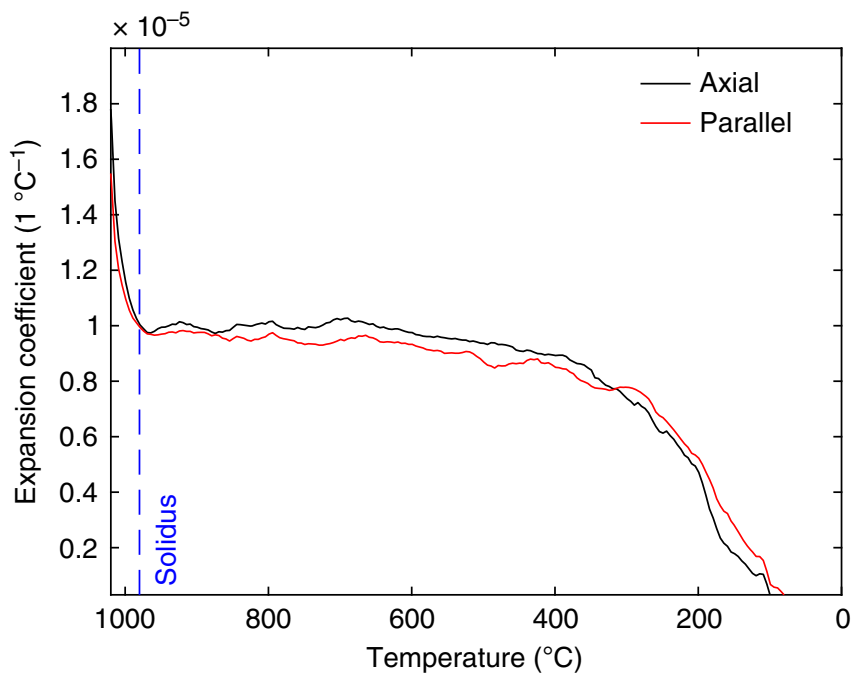

Fig. 4 Thermal expansion coefficient. Dilatometric measurements showing the linear expansion coefficient of Seljavellir basalt, cored axially and parallel to the column, during cooling from $1020^{\circ} \mathrm{C}$. The dashed blue line denotes the solidus temperature $\left(980^{\circ} \mathrm{C}\right)$ 
a

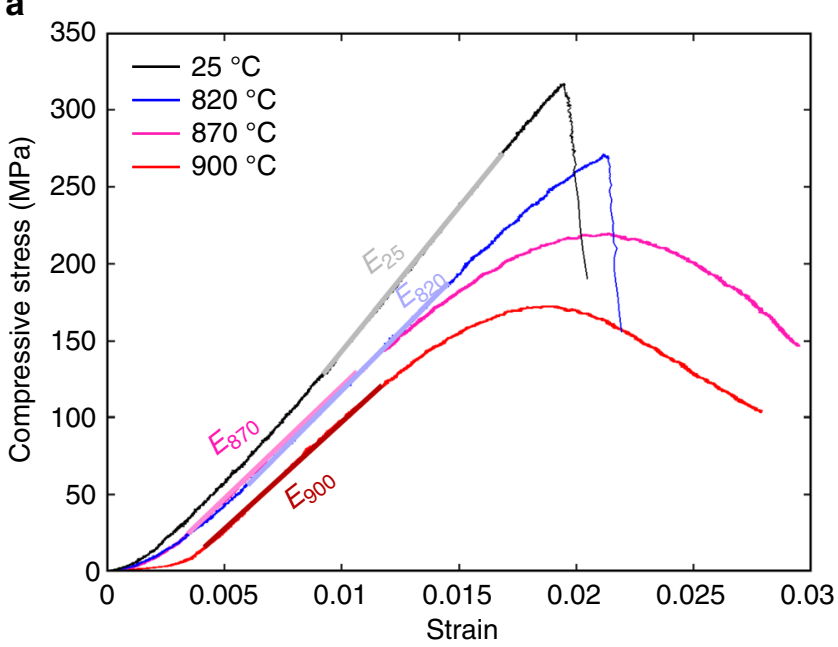

b

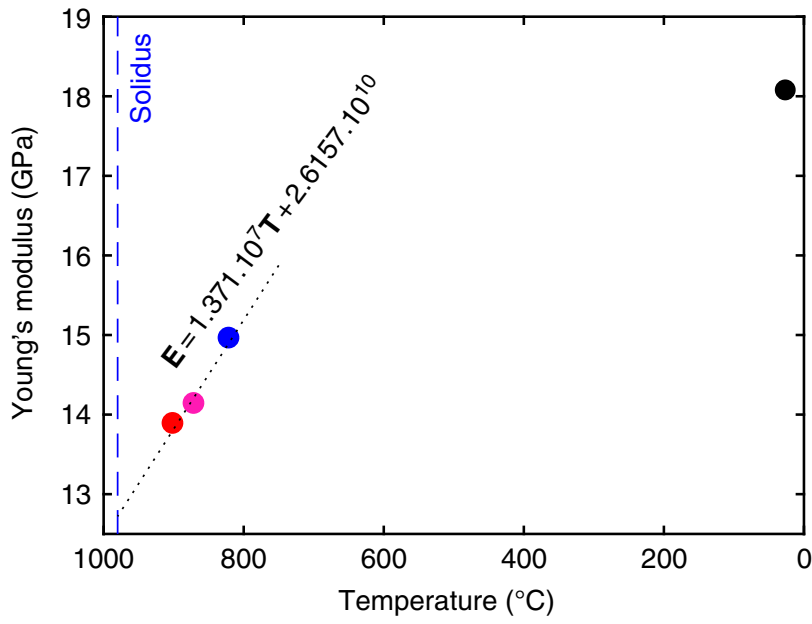

Fig. 5 Young's modulus variation with temperature. a Mechanical data obtained through uniaxial compressive testing at ambient temperature (black), 820 (blue), 870 (magenta) and $900^{\circ} \mathrm{C}$ (red). Young's moduli at the different temperatures $\left(E_{25}, E_{820}, E_{870}\right.$ and $\left.E_{900}\right)$ are calculated using the linear (elastic) portion of each curve. $\mathbf{b}$ Young's modulus values at each temperature, showing a linear evolution at high temperatures, as depicted by the dotted black line. The dashed blue line denotes the solidus temperature $\left(980^{\circ} \mathrm{C}\right)$

recorded in the combined thermo-mechanical jointing experiments. Together, these thermo-mechanical constraints allow us to model the tensile stress build-up over a range of undercooling $\Delta T$, via $\boldsymbol{\sigma}_{\mathbf{T}}=\mathbf{E} \alpha \Delta T^{31}$. Our calculations suggest that the temperature of macroscopic failure, $T_{\mathrm{f}}$, is $87-144^{\circ} \mathrm{C}$ below the solidus; that is, between 893 and $836^{\circ} \mathrm{C}$ (Fig. 6) - a temperature window in excellent agreement with the results of columnar jointing experiments developed here $\left(890-840^{\circ} \mathrm{C}\right.$; Fig. 3).

Modelling of fracture widening and fluid flow. Studies assessing the thermal history of magma reservoirs, sills and dykes often point towards arguably long cooling timescales if conduction alone is considered, and thus commonly infer the need for external fluid infiltration to increase the cooling efficiency of the magma body ${ }^{2,7,8}$. The thermo-mechanical constraints introduced here suggest that fluid infiltration may contribute to the thermal budget following columnar joint formation. Here the data reveal that after their formation at $890-840^{\circ} \mathrm{C}$, fractures would open by continued contraction proportional to an expansion coefficient of

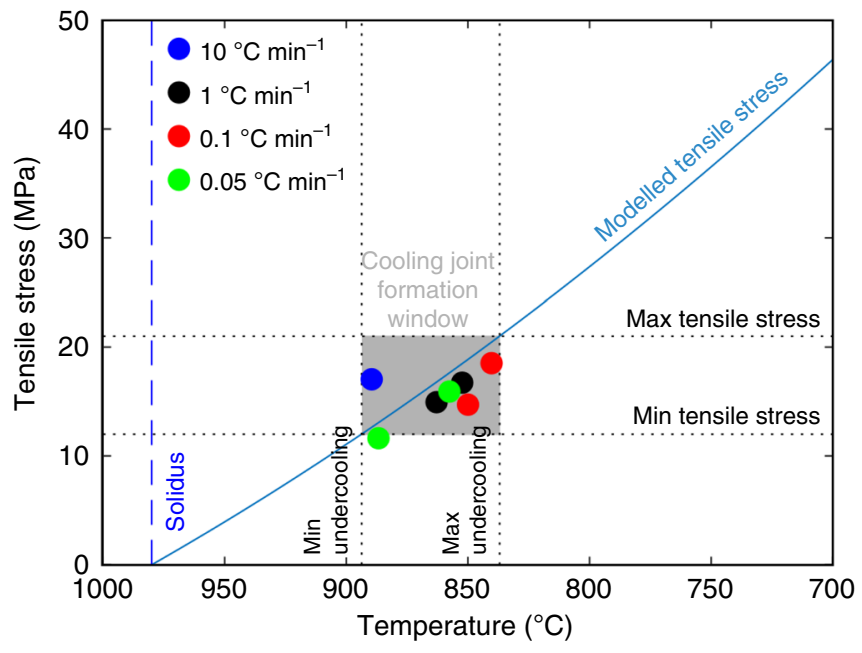

Fig. 6 Predicted columnar jointing temperature window. The horizontal dotted black lines show the minimum and maximum strength limits obtained through Brazilian tensile tests. The solid blue line shows the calculated tensile stress build-up upon cooling. The intercepts (vertical dotted lines) between the calculated stress curve and the measured strength lines denote the cooling window necessary to achieve failure. The coloured dots represent the fracturing temperatures achieved during columnar jointing experiments. The dashed blue line denotes the solidus temperature $\left(980^{\circ} \mathrm{C}\right)$

$\sim 10^{-5}{ }^{\circ} \mathrm{C}^{-1}$ down to $400^{\circ} \mathrm{C}$ (and at a slower rate below this temperature; Fig. 3), thereby constructing the permeable network that allows fluid infiltration in an otherwise largely impermeable rock (measured at $5 \times 10^{-20} \mathrm{~m}^{2}$ without fractures). Using the linear expansion coefficient $\alpha$ established for different temperatures $(T)$ by dilatometric measurements, we model the evolution of fracture width, $w$ due to contraction of the rock (between the centre of two columns with length $d_{\text {hot }}$ ) when cooling below the fracturing temperature $T_{\mathrm{f}}\left(893-836^{\circ} \mathrm{C}\right)$ :

$$
w=\alpha d_{\text {hot }}\left[T_{\mathrm{f}}-T\right]
$$

Here, we gauge the spectrum of $d_{\text {hot }}$ using the range of column sizes observed at Seljavellir $\left(d_{\text {cold }}=0.3-1.3 \mathrm{~m}\right)$ as proxy. Our calculation of the final fracture width shows good agreement with values of 1.9 and $8.3 \mathrm{~mm}$ measured in the field (Fig. 7a). Knowing the fracture width at different temperatures allows us to predict the permeability of a fractured rock mass, $\kappa_{\mathrm{fr}}\left(\right.$ in $\mathrm{m}^{2}$ ), contracting during cooling in the absence of stress, using a scaling for the permeability of fractured systems ${ }^{32}$. We modify this scaling to account for arrays of hexagonal columnar joints separated by fractures (see Methods) to find:

$$
\kappa_{\mathrm{fr}}=\frac{s \sqrt{3} \kappa_{\mathrm{h}}}{2 w+s \sqrt{3}}+\frac{w^{3}}{12 w+6 s \sqrt{3}}
$$

where $\kappa_{\mathrm{h}}$ is the permeability of the intact rock before jointing and $s$ is the edge-length of the colonnade hexagons (in $\mathrm{m}$ ). Thus, we calculate the permeability of columnar-jointed magmatic aureoles during cooling and show that the evolution is primarily, and highly dependent on the column size (Fig. 7b). Hence the formation of columnar joints may strongly influence hydrothermal circulation and therefore, the cooling history of magmatic bodies near the Earth's surface and in fluid-rich environments characteristic of shallow volcanic, geothermal and hydrothermal systems. 
a
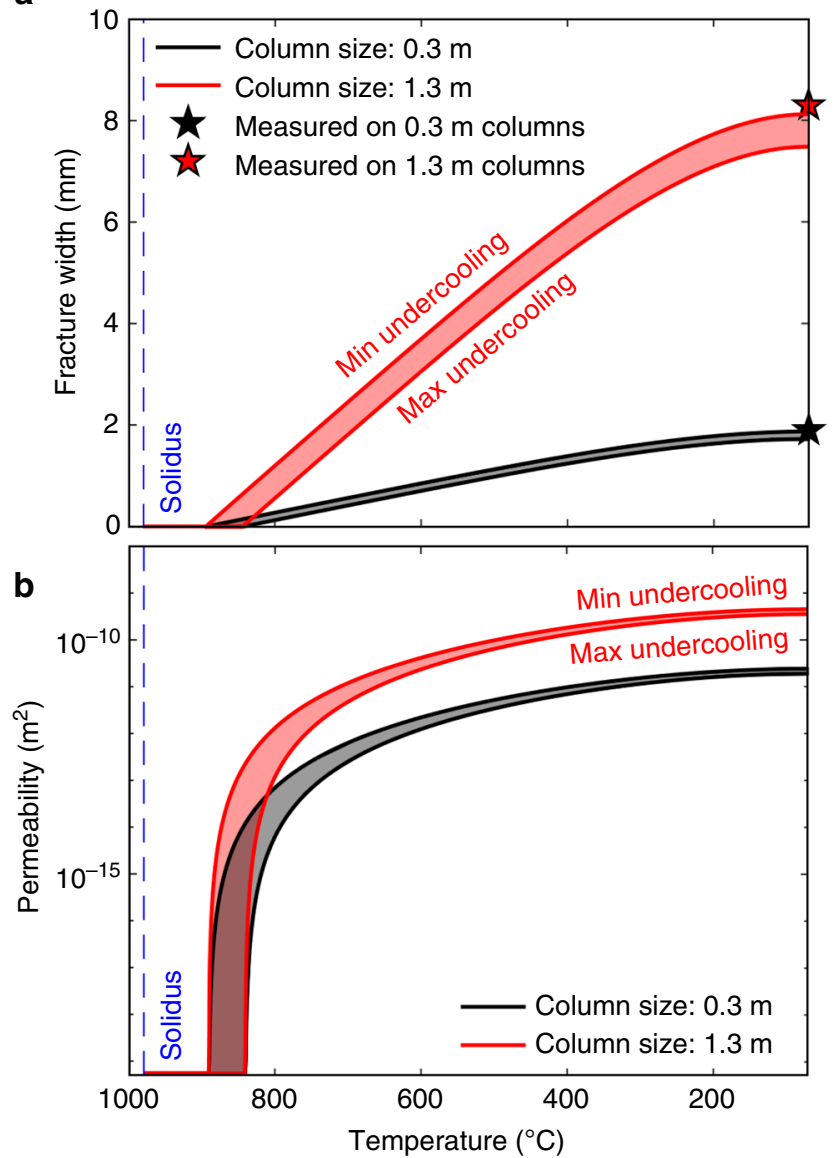

Fig. 7 Fracture width and permeability evolution of columnar-jointed rocks. a Fracture width evolution in a magmatic body developing columns of 0.3 (black) and $1.3 \mathrm{~m}$ (red) diameter. The black and red stars show the average fracture width, measured in the field, for 0.3 and $1.3 \mathrm{~m}$ diameter columns, respectively. $\mathbf{b}$ Permeability increase due to induced fracture opening in a cooling system with 0.3 (black) and $1.3 \mathrm{~m}$ (red) diameter columns. In both $\mathbf{a}$ and $\mathbf{b}$ the dashed blue line denotes the solidus temperature $\left(980^{\circ} \mathrm{C}\right)$

\section{Discussion}

Our results are consistent with incipient columnar joint formation at a relatively high temperature, yet within the range at which the magma body is fully elastic. Given that no stress accumulates at temperatures above the solidus (Fig. 3a, inset) and that an undercooling of at least $90^{\circ} \mathrm{C}$ (from the solidus) is required to induce tensile fracturing in this basalt, we advance that columnar joints must form and propagate in the solid state, at high-tomoderate temperatures. This thermal constraint in the subsolidus regime is in agreement with careful structural and petrographic observations recently put forth ${ }^{6}$, and thus suggests that the formation of columnar joints (at least those widespread in basaltic to basaltic-andesite lavas) by crossing of the glass transition of the melt ${ }^{24}$ can only happen in extremely rapidly cooled (more rapid than the rates herein), for example, in fluid-saturated environments.

Thermally induced columnar jointing leads to the construction of a fracture network with system permeability increasing non-linearly during cooling. The permeability gradient observed along a cooling column would allow sufficient water infiltration to trigger convection-driven cooling ${ }^{8}$ and eventually trigger quenching of liquid in the flow core, providing a mechanism for the formation of glass films observed along the entablatures $^{22}$. Drastic permeability increase during cooling of jointing bodies (Fig. 7b) may also explain why the aureoles of shallow magma bodies serendipitously encountered by geothermal drilling ${ }^{33,34}$ have very steep temperature gradients over short distances of a few tens of metres ${ }^{35,36}$. Drilling of these magmatic aureoles has been characterised by strong loss in drilling fluid circulation ${ }^{37}$; the results here suggest that efficient cooling by injection of fluids at $\sim 80^{\circ} \mathrm{C}$ in a magmatic aureole at ca. $850^{\circ} \mathrm{C}$ would have caused thermal jointing and a significant widening of fractures to allow drilling fluid circulation loss during drilling activity. Our results suggest that numerical simulations of natural cooling systems should incorporate thermo-mechanical constraints based on well-constrained experimental work to refine the limits of fluid circulation in volcanic, geothermal and hydrothermal environments.

\section{Methods}

Combined thermo-mechanical jointing experiments. Combined thermomechanical jointing experiments, mimicking columnar jointing, were conducted in the Experimental Volcanology and Geothermal Laboratory at the University of Liverpool in a 5969 Instron press equipped with a custom furnace designed by Severn Thermal Solutions, which permits infrared (IR) imaging of samples through a sapphire window. For this purpose, $170 \mathrm{~mm}$-long samples, $16 \mathrm{~mm}$ in diameter were cored out and the central $35 \mathrm{~mm}$ length of the sample was ground to a thinner dog-bone geometry with a diameter of $8-10 \mathrm{~mm}$, conferring a stress accuracy of $\pm 0.01 \mathrm{MPa}$ (using the standard error of estimate method, machine accuracy and sample geometry). During sample heating $\left(\right.$ at $5{ }^{\circ} \mathrm{C} \mathrm{min}^{-1}$ ) the grips were allowed to freely retract with sample expansion. Once the temperature equilibrated (after $30 \mathrm{~min}$ ), the grips were locked in position and the furnace was programmed to cool at set rates of $0.05,0.1,1$ or $10^{\circ} \mathrm{C} \mathrm{min}^{-1}$, whilst the press monitored tensile stress incurred by sample contraction. A FLIR SC6540 IR thermographic camera imaged sample temperature in response to the set rate of the furnace during cooling.

Dilatometry. Dilatometric measurements were performed at the University of Liverpool in a Thermo-Mechanical Analyser 402F1-Hyperion from Netzsch $\mathrm{GmbH}$. The expansion and contraction of a $6 \mathrm{~mm}$ diameter by $5 \mathrm{~mm}$-high cylindrical sample was monitored at a heating and cooling rate of $2{ }^{\circ} \mathrm{C} \mathrm{min}^{-1}$ (up to $1020^{\circ} \mathrm{C}$ ) with a spatial resolution of $0.125 \mathrm{~nm}$, whilst applying $3 \mathrm{mN}$ load. The sample expansion was corrected for sample holder expansion by subtracting a baseline run on a sample of standard alumina at the same heating and cooling rate. The corrected values of length changes were used to calculate the linear expansion coefficient.

Indirect tensile testing. Brazilian tests at room and high temperatures were conducted to assess the tensile strength ${ }^{38}$ in a 8800 Instron press equipped with a furnace designed by Severn Thermal Solutions, in the Experimental Volcanology and Geothermal Laboratory at the University of Liverpool. Disc-shaped samples with a diameter of $40 \mathrm{~mm}$ and a thickness of $20 \mathrm{~mm}$ were placed edgeon in the press and heated at $2{ }^{\circ} \mathrm{C} \mathrm{min}^{-1}$ to the desired sample temperature $\left(600-940^{\circ} \mathrm{C}\right.$ ), conferring a stress accuracy of $\pm 0.02 \mathrm{MPa}$ (using the standard error of estimate method, machine accuracy and sample geometry). After $1 \mathrm{~h}$ of thermal equilibration at the target temperature, the cylindrical sample was diametrically compressed at a rate of $4 \times 10^{-4} \mathrm{~mm} \mathrm{~s}^{-1}$ with force and deformation monitored until complete failure. Room temperature tests were conducted at the same rate.

Young's modulus measurements. The temperature-dependence of the static Young's modulus was constrained by conducting a series of uniaxial compressive strength tests in a 8800 Instron press in the Experimental Volcanology and Geothermal Laboratory at the University of Liverpool. Cylindrical samples with a diameter of $10 \mathrm{~mm}$ and length of $20 \mathrm{~mm}$ were placed between the pistons of the press and heated at a rate of $2^{\circ} \mathrm{C} \mathrm{min}^{-1}$ to the desired sample temperatures $\left(820-900^{\circ} \mathrm{C}\right)$ centred around $T_{\mathrm{f}}$. Once thermally equilibrated $(30$ $\mathrm{min}$ ), the cylinders were deformed at a rate of $10^{-5} \mathrm{~s}^{-1}$ and stress and strain were monitored. The linear portion of the stress-strain data was used to constrain the static Young's modulus, with an accuracy of $\pm 0.03 \mathrm{GPa}$ (using the standard error of estimate method, machine accuracy, sample geometry and sample strength).

Permeability determination. The permeability of the rock was measured in the Experimental Volcanology and Geothermal Laboratory at the University of Liverpool in a Sanchez hydrostatic vessel, using water pressures (in) of 2.1 MPa and (out) of $0.1 \mathrm{MPa}$ (thus a pore pressure gradient, $\triangle P=2 \mathrm{MPa}$ ), and $6 \mathrm{MPa}$ confining pressure exerted by oil on a jacketed cylindrical sample ( $25 \mathrm{~mm}$ diameter). Water 
volumetric discharge rate, $Q$ (in $\mathrm{m}^{3} \mathrm{~s}^{-1}$ ) was monitored and used to calculate the permeability, $\kappa$, via Darcy's equation ${ }^{39,40}$ :

$$
\kappa=\frac{Q \eta L}{A \Delta P}
$$

where $A$ is the sample cross-sectional area $\left(\mathrm{m}^{2}\right), L$ the sample length $(\mathrm{m})$ and $\eta$ the viscosity of the fluid (0.001 Pa s for water).

Modelling of fluid flow in a jointed body. To model the permeability, $\kappa_{\mathrm{s}}$, of a reservoir developing columnar joints, we use a simple scaling ${ }^{32}$ modified for a twodimensional areal case:

$$
\kappa_{\mathrm{s}}=\frac{A_{\mathrm{h}} \kappa_{\mathrm{h}}}{A_{\mathrm{i}}}+\frac{A_{\mathrm{f}} \kappa_{\mathrm{f}}}{A_{\mathrm{i}}}
$$

where $\kappa_{\mathrm{h}}$ is the permeability of the intact rock, $A_{\mathrm{h}}$ is the two-dimensional top-area of impermeable columns perpendicular to the fracture propagation direction, $A_{\mathrm{f}}$ is the area of the fractures, $A_{\mathrm{i}}$ is the total area (as the sum of $A_{\mathrm{f}}$ and $A_{\mathrm{h}}$ ) and $\kappa_{\mathrm{f}}$ is the permeability of a fracture.

Considering the system shown in Fig. 1 and applying it to Seljavellir basalts, we define the following set of parameters. Assuming hexagonal columns, the area of a unit cell of two impermeable columns, $A_{\mathrm{h}}$, is given by:

$$
A_{\mathrm{h}}=3 \sqrt{3} s^{2}
$$

The fractured area $A_{\mathrm{f}}$ is given by the six fracture edges in the unit cell of two hexagons as:

$$
A_{\mathrm{f}}=6 s w
$$

Applying Poiseuille's law for fluid flow in an infinite slot, we can derive the permeability of a fracture, $\kappa_{\mathrm{f}}$, as:

$$
\kappa_{\mathrm{f}}=\frac{w^{2}}{12}
$$

Substituting Eqs. 5-7 into Eq. 4, we find that the permeability of the jointing system follows a simple analytical form, which depends only on $\kappa_{\mathrm{h}}, s$ and $w$, shown in Eq. 2.

Data availability. The authors declare that all data supporting the findings of this study are available within the paper and its Supplementary Information files.

Received: 16 October 2014 Accepted: 16 March 2018

Published online: 12 April 2018

\section{References}

1. Kantha, L. H. Basalt fingers-origin of columnar joints. Geol. Mag. 118, 251-264 (1981).

2. Degraff, J. M. \& Aydin, A. Effect of thermal regime on growth increment and spacing of contraction joints in basaltic lava. J. Geophys. Res. Solid Earth 98, 6411-6430 (1993).

3. Laboulais-Lesage, I. Seeing, combining and describing: physical geography according to Nicolas Demarest. Rev. D. Hist. Mod. Et. Contempt. 51, 38-57 (2004).

4. Goehring, L. \& Morris, S. W. Order and disorder in columnar joints. Europhys. Lett. 69, 739-745 (2005)

5. Phillips, J. C., Humphreys, M. C. S., Daniels, K. A., Brown, R. J. \& Witham, F. The formation of columnar joints produced by cooling in basalt at Staffa, Scotland. Bull. Volcanol. 75, 17 (2013).

6. Mattsson, H. B. et al. Melt migration in basalt columns driven by crystallization-induced pressure gradients. Nat. Commun. 2, 299 (2011).

7. Carrigan, C. R. A 2-phase hydrothermal cooling model for shallow intrusions. J. Volcanol. Geotherm. Res. 28, 175-192 (1986).

8. Lister, C. R. B. Qualitative models of spreading-center processes, including hydrothermal penetration. Tectonophysics 37, 203-218 (1977).

9. King, J., Williams-Jones, A. E., van Hinsberg, V. \& Williams-Jones, G. Highsulfidation epithermal pyrite-hosted $\mathrm{Au}(\mathrm{Ag}-\mathrm{Cu})$ ore formation by condensed magmatic vapors on Sangihe Island, Indonesia. Econ. Geol. 109, 1705-1733 (2014).

10. Xu, T. F., Sonnenthal, E., Spycher, N. \& Pruess, K. TOUGHREACT-a simulation program for non-isothermal multiphase reactive geochemical transport in variably saturated geologic media: applications to geothermal injectivity and $\mathrm{CO} 2$ geological sequestration. Comput. Geosci. 32, 145-165 (2006).

11. Barton, N., Bandis, S. \& Bakhtar, K. Strength, deformation and conductivity coupling rock joints. Int. J. Rock Mech. Min. Sci. 22, 121-140 (1985).

12. Milazzo, M. P. et al. Discovery of columnar jointing on Mars. Geology 37, 171-174 (2009).

13. Tomkeieff, S. L. The basalt lavas of the Giant's Causeway district of northern Ireland. Bull. Volcanol. 6, 89-143 (1940).

14. Spry, A. The origin of columnar jointing, particularly in basalt flows. J. Geol. Soc. Aust. 8, 27 (1962).

15. Saemundsson, K. Interglacial lava flows in the lowlands of southern Iceland and the problem of two-tiered columnar jointing. Jokull 20, 62-77 (1970).

16. Goehring, L. \& Morris, S. W. Scaling of columnar joints in basalt. J. Geophys Res. 113, 18 (2008).

17. Grossenbacher, K. A. \& McDuffie, S. M. Conductive cooling of lava: columnar joint diameter and stria width as functions of cooling rate and thermal gradient. J. Volcanol. Geotherm. Res. 69, 9 (1995).

18. Budkewitsch, P. \& Robin, P. Y. Modeling the evolution of columnar joints. J. Volcanol. Geotherm. Res. 59, 219-239 (1994).

19. Rieter, M., Barroll, M. W., Minier, J. \& Clarkson, G. Thermomechanical model for incremental fracturing in lava flows. Tectonophysics 142, 241-262 (1987).

20. Grossenbach, K. A. \& McDuffie, S. M. Conductive cooling of lava: columnar joint diameter and stria width as functions of cooling rate and thermal gradient. J. Volcanol. Geotherm. Res. 69, 95-103 (1995).

21. Browning, J., Meredith, P. \& Gudmundsson, A. Cooling-dominated cracking in thermally stressed volcanic rocks. Geophys. Res. Lett. 43, 8417-8425 (2016).

22. Forbes, A. E. S., Blake, S. \& Tuffen, H. Entablature: fracture types and mechanisms. Bull. Volcanol. 76, 13 (2014).

23. Lore, J., Gao, H. \& Aydin, A. Viscoelastic thermal stress in cooling basalt flows. J. Geophys. Res. 105, 15 (2000).

24. Ryan, M. P. \& Sammis, C. G. The glass-transition in basalt. J. Geophys. Res. 86, 9519-9535 (1981).

25. Symons, D. T. A. Magnetic and petrologic properties of a basalt. Geophys. J. R. Astron. Soc. 12, 473-\& (1967).

26. Dingwell, D. B. Transport properties of magmas: diffusion and rheology. Elements 2, 281-286 (2006).

27. Gottsmann, J., Harris, A. J. L. \& Dingwell, D. B. Thermal history of Hawaiian pahoehoe lava crusts at the cylass transition: implications for flow rheology and emplacement. Earth Planet. Sci. Lett. 228, 343-353 (2004).

28. Nichols, A. R. L., Potuzak, M. \& Dingwell, D. B. Cooling rates of basaltic hyaloclastites and pillow lava glasses from the HSDP2 drill core. Geochim. Cosmochim. Acta 73, 1052-1066 (2009).

29. Potuzak, M., Nichols, A. R. L., Dingwell, D. B. \& Clague, D. A. Hyperquenched volcanic glass from Loihi Seamount, Hawaii. Earth Planet. Sci. Lett. 270, 54-62 (2008).

30. Gaetani, G. A., Ghiorso, M. S., Sack, R. O., Hirschmann, M. \& Asimow, P. D. MELTS. Science 282, 1834-1835 (1998).

31. Jaeger, J. C., Cook, N. G. \& Zimmerman, R. Fundamentals of Rock Mechanics 4th edn (John Wiley \& Sons, 2009).

32. Zimmerman, R. W. \& Bodvarsson, G. S. Hydraulic conductivity of rock fractures. Transp. Porous Media 23, 1-30 (1996).

33. Elders, W. A., Fridleifsson, G. O. \& P lsson, B. Iceland Deep Drilling Project: the first well, IDDP-1, drilled into magma. Geothermics 49, 111-118 (2014).

34. Teplow, W. et al. Dacite Melt at the Puna Geothermal Venture Wellfield, Big Island of Hawaii. In Geothermal Resources Council Annual Meeting.Vol. 33 (Geothermal Resources Council, Oxford, UK, 2009).

35. Mortensen, A., Egilson, P, Gautason, B., Árnadóttir, S. \& Guðmundsson, Á. Stratigraphy, alteration mineralogy, permeability and temperature conditions of well IDDP-1, Krafla, NE-Iceland. Geothermics 49, 31-41 (2014).

36. Axelsson, G., Egilson, T. \& Gylfadóttir, S. S. Modelling of temperature conditions near the bottom of well IDDP-1 in Krafla, Northeast Iceland. Geothermics 49, 49-57 (2014).

37. Pálsson, B. et al. Drilling of the well IDDP-1. Geothermics 49, 23-30 (2014).

38. Mahabadi, O. K., Cottrell, B. E. \& Grasselli, G. An example of realistic modelling of rock dynamics problems: FEM/DEM simulation of dynamic Brazilian Test on Barre Granite. Rock Mech. Rock Eng. 43, 707-716 (2010).

39. Darcy, H. Les fontaines publiques de la ville de Dijon (Victor Dalmont, 1856)

40. Darcy, H. Recherches expérimentales relatives au mouvement de l'eau dans les tuyaux (Mallet-Bachelier, Paris, 1857).

\section{Acknowledgements}

Y.L. thanks Prof. A.E (Willy) Williams-Jones whose stimulating teaching inspired the development of this scientific question and its undertaking. Y.L. acknowledges support from the European Research Council for the Starting Grant on Strain Localisation in Magma (SLiM, no. 306488). J.E.K was supported by an Early Career Fellowship of 
Leverhulme Trust (ECF 2016-325) during the final phase of research and revision of the manuscript.

\section{Author contributions}

Y.L. conceptualised the original idea. Y.L., F.E.I. and J.E.K. surveyed columnar joints exposure. A.L., Y.L., F.E.I., F.B.W. and J.E.K. performed columnar jointing experiments. A.L. conducted Young's modulus measurement experiments. F.E.I., A.J.H. and A.L. performed high-temperature Brazilian tests, F.W.v.A. and F.E.I. performed the dilatometric tests. All co-authors contributed to the manuscript.

\section{Additional information}

Supplementary Information accompanies this paper at https://doi.org/10.1038/s41467018-03842-4

Competing interests: The authors declare no competing interests.

Reprints and permission information is available online at http://npg.nature.com/ reprintsandpermissions/
Publisher's note: Springer Nature remains neutral with regard to jurisdictional claims in published maps and institutional affiliations.

(c) (i) Open Access This article is licensed under a Creative Commons Attribution 4.0 International License, which permits use, sharing, adaptation, distribution and reproduction in any medium or format, as long as you give appropriate credit to the original author(s) and the source, provide a link to the Creative Commons license, and indicate if changes were made. The images or other third party material in this article are included in the article's Creative Commons license, unless indicated otherwise in a credit line to the material. If material is not included in the article's Creative Commons license and your intended use is not permitted by statutory regulation or exceeds the permitted use, you will need to obtain permission directly from the copyright holder. To view a copy of this license, visit http://creativecommons.org/ licenses/by/4.0/.

(C) The Author(s) 2018 